\title{
Genetic Basis of the Crown-Size Profile Pattern
}

\author{
STANLEY M. GARN, ARTHUR B. LEWIS, and ARLINE J. WALENGA
}

Center for Human Growth, University of Michigan, Ann Arbor, Michigan and Fels Research Institute, Yellow Springs, Ohio

\begin{abstract}
Although genetic control of crown diameters has been documented by a number of workers (R. H. OSBORNE ET AL, Amer J Hum Genet 10: 350-356, 1958; S. M. GARN ET AL, $J$ Dent Res 44:228-242, 1965 ; D. W. LEWIS and R. M. GraINGER, Arch Oral Biol 12:539-544, 1967; and D. H. Goose, J Dent Res 46:959-962, 1967), genetic involvement in crown-size patterning has not been ascertained for the whole dentition.

To investigate the genetic and chromosomal basis of crown-size profile patterning, crownsize patterns of 960 pairs of subjects from southwestern Ohio were compared. After converting individual measurements into normalized $T$ scores (W. A. MCCALL, Measurement, 1939 , pp 505-508) by using a computer program (C. R. Black, Ann NY Acad Sci 134: $538-540$, 1966), dentitions of each pair of subjects were compared by the product moment correlation, $r$. The resulting correlation coefficients $\left(r_{T}\right)$, involving $T$-scored values of corresponding teeth, provided a simple expression of the degree of patterned similarity between any two individuals. The use of normalized $T$ scores automatically corrected for sex made possible cross-sexed as well as like-sexed comparisons.
\end{abstract}

Sibling correlations for tooth-size similarity approximated 0.22 for 246 like-sexed and crosssexed brothers and sisters (Table). Parent-child similarities in crown-size profile pattern approximated 0.20 as shown by 90 parent-child pairings. Similariy investigated, 58 pairs of cousins yielded a mean similarity coefficient value of 0.15 . Finally, randomly paired, unrelated subjects had a pattern profile similarity value of 0.01 , close to the theoretical 0.00 value. With profile-pattern similarity values ranging from 0.90 for monozygotic female twins through 0.20 for parents versus their children, 0.15 for cousins, and 0.00 for unrelated pairs, it is clear that crown-size profile patterns have a genetic basis.

The values in the table also show evidence for X-chromosomal involvement in the pattern of the total dentition. Sister-sister values of $r_{T}$ exceeded the remaining sibling correlations.

This work was supported by USPHS Research Grants DE-01294 and FR-00222 from the National Institutes of Health, Bethesda, Md.

Additional information is available on request to the authors.

Received for publication March 20, 1968.
Parent-Child, Sibling, and Cousin RESEMBLANCES IN CROWN-SIZE Profile Patterns

\begin{tabular}{|c|c|c|}
\hline \multirow{2}{*}{$\begin{array}{l}\text { Type of } \\
\text { Comparison }\end{array}$} & \multirow[b]{2}{*}{$\mathrm{N}$} & \multirow{2}{*}{$\frac{\text { Mean }}{r r^{*}}$} \\
\hline & & \\
\hline \multicolumn{3}{|l|}{ Sibling } \\
\hline Sister-sister & 67 & 0.256 \\
\hline Brother-brother & 65 & 0.117 \\
\hline Brother-sister & 114 & 0.219 \\
\hline All & 246 & 0.218 \\
\hline \multicolumn{3}{|l|}{ Parent-child } \\
\hline Father-daughter & 29 & 0.256 \\
\hline Father-son & 19 & -0.045 \\
\hline Mother-daughter & 28 & 0.310 \\
\hline Mother-son & 14 & 0.162 \\
\hline All & 90 & 0.195 \\
\hline \multicolumn{3}{|l|}{ Cousin } \\
\hline Female cousins & 23 & 0.168 \\
\hline Male cousins & 8 & 0.119 \\
\hline Male-female cousins & 27 & 0.148 \\
\hline All cousins & 58 & 0.152 \\
\hline \multicolumn{3}{|l|}{ Random pairings } \\
\hline Females & 50 & -0.011 \\
\hline Males & 56 & 0.034 \\
\hline Male-female & 66 & 0.007 \\
\hline
\end{tabular}

* Left side, except where a corresponding tooth on the right side was substituted because of missing data.

Moreover, father-daughter crown-size profile patterns were more alike $\left(r_{T}=0.26\right)$ than father-son correlations $\left(r_{T}=-0.04\right)$, again in accordance with the hypothesis of X-chromosomal mediation.

Taking twin, sibling, parent-child, and cousin similarities in crown-size profile patterning into account, using the statistic $r_{T}$ throughout, it is estimated that $80 \%$ to $90 \%$ of patterned variance in crown size has a genetic basis, most of which can be attributed to a combination of autosomal genes and genes located on the $X$ chromosome. Finally, from the excess of sistersister over brother-brother values of $r_{T}$ and the excess of father-daughter over father-son values, it would appear that a greater proportion of crown-size profile pattern variance is controlled by relatively few genes on the $X$ chromosome than by the larger number on the remaining 22 pairs of autosomes.

Ova D. Goins of the Fels Computer Facility assisted in the computer programming for the statistic $r_{T}$, and Edmund Churchill made statistical studies. 